\title{
Prognostic value of serum fibrinogen-related antigen levels after myocardial infarction
}

\author{
Adrian V. Simmons, ${ }^{1}$ Margaret A. Sheppard, Robert Sibbald, Geoffrey Tate, and Brian E. Roberts \\ From the Departments of Medicine and Medical Physics, Bradford Royal Infirmary; and Department of \\ Haematology, General Infirmary, Leeds
}

Serum fibrinogen-related antigen levels have been determined daily for II days after myocardial infarction in 55 patients. Raised levels were found in only 17 of these at some time during the study, suggesting that the estimation is of little value in diagnosis. Prognosis was assessed by the use of the 'coronary prognostic index'. From day 5 to day 8 a positive correlation was demonstrated between high fibrinogen-related antigen levels and poor prognosis. On some days mean antigen values were higher in patients with deep venous thrombosis, but the presence of this complication appears to have little influence on the prognostic value of the fibrinogenrelated antigen level.

Detection of fibrinogen-related antigen in serum is a measure of the extent of fibrinogen/fibrin digestion by proteolytic enzymes. It is now realized that circulating fibrinogen-related antigen can be derived not only from plasmin digestion of fibrin deposited intravascularly, but also from its digestion by less specific proteolytic enzymes acting at extravascular sites. Merskey and Johnson (197I), Das et al. (1967), and Wood, Prentice, and McNicol, (1972), in a study of the association of fibrinogenrelated antigen values with postoperative deep venous thrombosis, found that the highest values occurred in those patients who, in addition to deep venous thrombosis, had systemic complications such as sepsis, heart failure, or metastatic disease. They suggested that fibrinogen-related antigen was produced partly by diffuse cellular damage.

After intravenous injection of ${ }^{125}$ I-labelled fibrinogen, we have shown (Simmons, Sheppard, and Cox, 1972) that there is variable accumulation of radioactivity in the heart shortly after myocardial infarction. It is likely that this accumulation represents, in part, the deposition of fibrin in the infarcted area. It is, therefore, not unreasonable to expect that serum fibrinogen-related antigen values may become raised under these circumstances.

Evidence recently available (Baele, Mussche, and Vermeire, 1972; Almer, Hedner, and Nilsson, 1972) suggests that raised values are not frequently found after myocardial infarction. The authors of these

Received 7 May, 1973.

1 Present address: Chapel Allerton Hospital, Leeds 7. reports consider that an increased value observed shortly after myocardial infarction indicates a poor prognosis.

In this investigation we have measured serum fibrinogen-related antigen levels daily after myocardial infarction. An attempt has been made to determine the prognostic value of these levels by comparison with the prognostic index of Norris et al. (I969). The development of deep venous thrombosis was detected in these patients and its overall effects on daily fibrinogen-related antigen levels determined. We have also endeavoured to assess whether the presence of a deep venous thrombosis alters the prognostic significance of the antigen value.

\section{Patients and methods}

Fifty-five patients were studied. All were admitted to the coronary care ward at Bradford Royal Infirmary shortly after the occurrence of myocardial infarction. Initial selection depended on the decision made by the admitting medical officer that the diagnosis of myocardial infarction was highly probable and also on the availability of ${ }^{125}$ I-labelled fibrinogen. Final inclusion to the study was dependent on the occurrence of characteristic electrocardiographic changes and a rise in serum enzymes.

\section{Fibrinogen-related antigen assay}

This was assayed by the tanned red cell haemagglutination-inhibition technique (Merskey, Kleiner, and Johnson, 1966). Blood was taken on the morning after admission and thereafter daily except on Sundays for Io days. Ten millilitres were added to glass tubes 
containing Trasylol and allowed to clot while standing in a water bath at $37^{\circ} \mathrm{C}$ for 2 hours before centrifugation. Samples were then deep frozen at $-20^{\circ} \mathrm{C}$ until assay. Thrombin was added before assay in order to remove traces of fibrinogen.

\section{Detection of deep venous thrombosis}

The presence of deep venous thrombosis was detected by leg scanning daily for to days after the injection of ${ }^{125}$ I-labelled fibrinogen on the morning after admission. Full details of the method have been described elsewhere (Simmons et al., 1972).

\section{Coronary prognostic index}

This was calculated for each patient according to the original method of Norris et al. (1969). The index is derived from numerical weightings given to 6 measurable factors associated with hospital mortality from acute myocardial infarction. These are age, site of infarction, systolic blood pressure on admission, history of previous ischaemic heart disease, and heart size together with the degree of pulmonary congestion assessed from a chest $x$-ray. A high coronary prognostic index indicates a poor prognosis and vice versa.

\section{Results}

The Fig. shows the daily serum fibrinogen-related antigen values in 55 patients, together with the normal range for this laboratory. Individual results fell in a range starting at $\mathrm{r} \cdot 25 \mu \mathrm{g} / \mathrm{ml}$, and ascending by double dilutions to $160 \mu \mathrm{g} / \mathrm{ml}$, thus giving values of $\mathrm{I} \cdot 25,2.5,5 \cdot 0 \ldots \mu \mathrm{g} / \mathrm{ml}$. The occurrence of one or two very high results gives excessive weighting to the determination of mean values. Consequently all results were converted to logarithms to the base 2, means and standard deviations being calculated on this basis. The results were then reconverted to fibrinogen-related antigen levels and are given in Table I for patients with and without deep venous thrombosis.

The number of patients with values above the normal range was similar each day; 22 patients had raised values at some time during the study. Values were raised for a mean of 2.7 days; single high results were found in only 4 patients. A small subgroup of 3 patients was identified in which high fibrinogen-related antigen levels, including values of at least $80 \mu \mathrm{g} / \mathrm{ml}$, were obtained over several days.

It can be seen that there is a tendency for the mean serum values to rise in the first few days after myocardial infarction. In those patients who developed deep venous thrombosis ' $t$ ' testing reveals significantly higher mean values on days $\mathrm{I}, 3, \mathrm{IO}$,

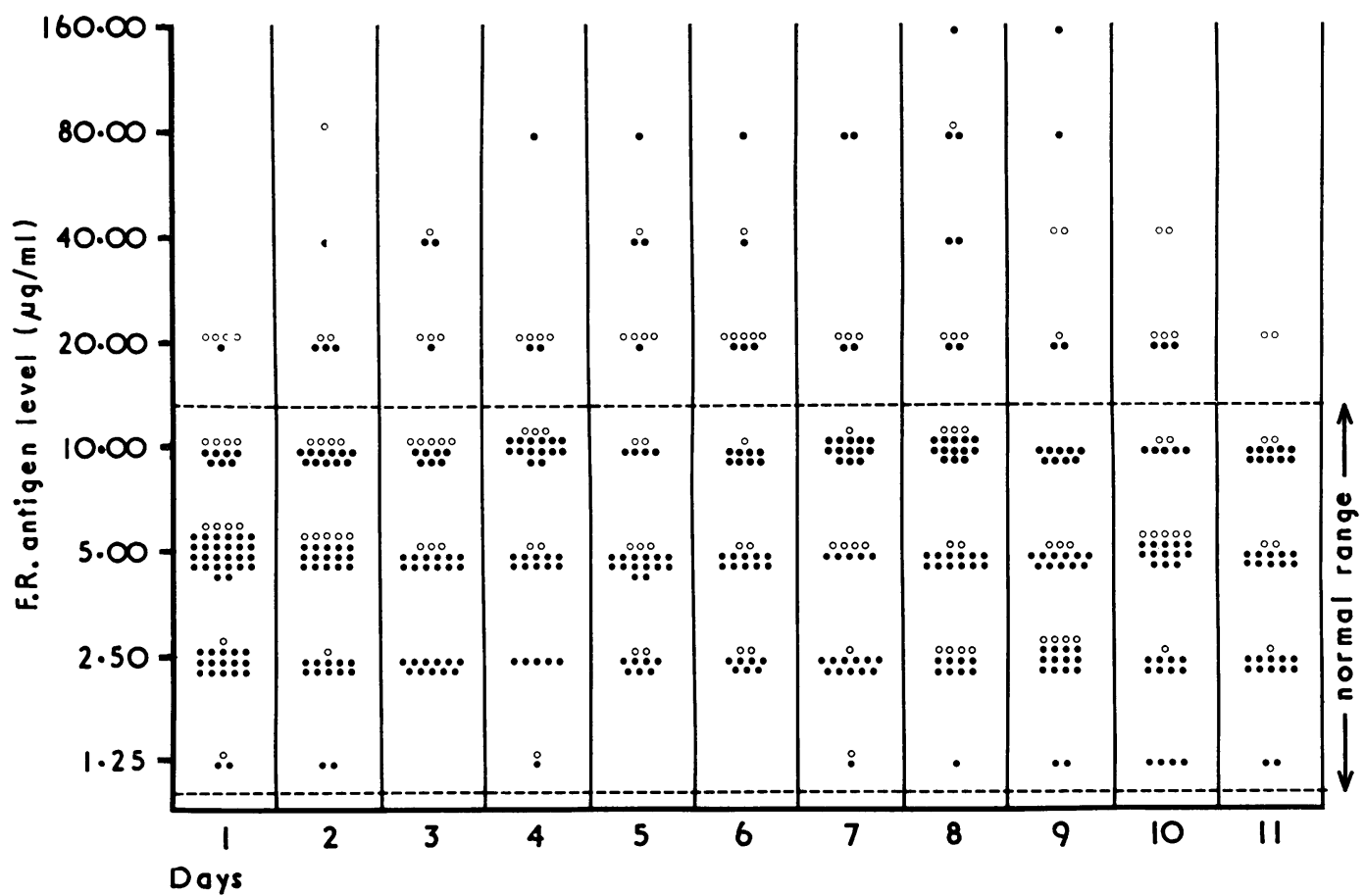

FIG. Fibrinogen-related antigen levels in patients with and without deep venous thrombosis. Duplicate estimations were carried out on each sample. If values differed, both results appear on the figure.

= patients without deep vein thrombosis; $\mathrm{O}=$ patients with deep vein thrombosis. 
TABLE I Fibrinogen-related antigen levels in patients with and without deep venous thrombosis

\begin{tabular}{|c|c|c|c|c|c|c|c|}
\hline \multirow[t]{3}{*}{ Day } & \multicolumn{4}{|c|}{ Fibrinogen-related antigen levels } & \multirow[t]{3}{*}{ ' $t$ ' } & \multirow[t]{3}{*}{ Significance } & \multirow[t]{3}{*}{ Paired ' $t$ ' } \\
\hline & \multicolumn{2}{|c|}{$\begin{array}{l}\text { Without deep venous } \\
\text { thrombosis }\end{array}$} & \multicolumn{2}{|c|}{$\begin{array}{l}\text { With deep venous } \\
\text { thrombosis }\end{array}$} & & & \\
\hline & Mean & $S D$ & Mean & $S D$ & & & \\
\hline $\mathbf{I}$ & $4 \cdot 3$ & $\mathbf{I} \cdot 7$ & $7 \cdot 9$ & $\mathbf{2 \cdot 2}$ & $3 \cdot 3$ & $99 \%$ & 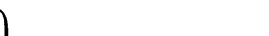 \\
\hline 2 & 5.5 & $2 \cdot 1$ & $9 \cdot 0$ & $2 \cdot 3$ & $\mathrm{I} \cdot 96$ & NS & \\
\hline 3 & $5 \cdot 4$ & $2 \cdot \mathbf{I}$ & II 2 & $I \cdot 9$ & $2 \cdot 90$ & $99 \%$ & \\
\hline 4 & $6 \cdot 8$ & $2 \cdot \mathbf{I}$ & $9 \cdot 3$ & $2 \cdot 3$ & I.07 & NS & \\
\hline 5 & $6 \cdot 2$ & $2 \cdot 4$ & $9 \cdot 0$ & $2 \cdot 3$ & $\mathbf{I} \cdot \mathbf{2 1}$ & NS & \\
\hline 6 & 6.9 & $2 \cdot 3$ & $10 \cdot 6$ & $2 \cdot 5$ & I.37 & NS & $5.2999 \%$ significant \\
\hline 7 & $6 \cdot 4$ & $2 \cdot 6$ & $6 \cdot 6$ & $2 \cdot 4$ & 0.10 & NS & \\
\hline 8 & $7 \cdot 7$ & $2 \cdot 8$ & $8 \cdot 0$ & $2 \cdot 8$ & 0.12 & NS & \\
\hline 9 & 5.6 & $2 \cdot 7$ & $6 \cdot 6$ & 2.9 & 0.45 & NS & \\
\hline IO & $4 \cdot 6$ & $2 \cdot 2$ & $10 \cdot 0$ & $2 \cdot 4$ & 2.93 & $99 \%$ & \\
\hline II & $4 \cdot 6$ & $1 \cdot 9$ & $8 \cdot I$ & $2 \cdot 0$ & 2.05 & $99 \%$ & \\
\hline
\end{tabular}

and II. A paired ' $t$ ' test indicates that, overall, patients with deep venous thrombosis have significantly higher values than those who did not develop this complication.

The statistical relation between fibrinogenrelated antigen levels and coronary prognostic index was approached in three ways.

First, the correlation between daily fibrinogenrelated antigen levels and coronary prognostic index was examined. The findings are set out in Table 2. Patients have been divided into two categories: I) All patients, and 2) those patients without deep venous thrombosis. When all patients are considered, a significant correlation between these two parameters is found from day 5 to day 10 . In patients without deep venous thrombosis the correlation coefficients are significant from day 5 to day 8 .
Secondly, the correlation coefficient of coronary prognostic index and the highest fibrinogen-related antigen level measured in each patient over the period of study (hereafter called 'the maximum fibrinogen-related antigen level') was calculated. This is also shown in Table 2. A significant correlation was obtained when all patients were considered but not when those with deep venous thrombosis were excluded. Only 13 of the 55 patients developed deep venous thrombosis, and this incidence is not sufficient for the determination of any correlation between the fibrinogen-related antigen level and the coronary prognostic index in this group.

Thirdly, as it seemed possible that the prognostic value of fibrinogen-related antigen level was restricted to serum levels greater than normal, patients were redivided into (a) those with maximum

TABLE 2 Correlation coefficients between fibrinogen-related antigen levels and coronary prognostic index

\begin{tabular}{|c|c|c|c|c|}
\hline \multirow[t]{3}{*}{ Day } & \multicolumn{2}{|c|}{ All patients } & \multirow{2}{*}{\multicolumn{2}{|c|}{$\begin{array}{l}\text { Without deep venous } \\
\text { thrombosis }\end{array}$}} \\
\hline & \multirow[t]{2}{*}{ ' $r$ ' } & \multirow{2}{*}{ Significance } & & \\
\hline & & & ' $r$ ' & Significance \\
\hline $\mathbf{I}$ & 0.104 & NS & 0.127 & NS \\
\hline 2 & 0.107 & NS & 0.239 & NS \\
\hline 3 & 0.152 & NS & 0.196 & NS \\
\hline 4 & 0.289 & NS & 0.300 & NS \\
\hline 5 & 0.523 & $99 \%$ & $0.44 I$ & $95 \%$ \\
\hline 6 & 0.563 & $99 \%$ & 0.886 & $99 \%$ \\
\hline $\begin{array}{l}7 \\
8\end{array}$ & $\begin{array}{l}0.600 \\
0.802\end{array}$ & $99 \%$ & $\begin{array}{l}0.565 \\
0.394\end{array}$ & $99 \%$ \\
\hline 9 & $\begin{array}{l}0.802 \\
0.593\end{array}$ & $\begin{array}{l}99 \% \\
99 \%\end{array}$ & $\begin{array}{l}0.394 \\
0.054\end{array}$ & $\begin{array}{l}98 \% \\
\text { NS }\end{array}$ \\
\hline 10 & 0.580 & $99 \%$ & 0.339 & NS \\
\hline \multirow{3}{*}{$\begin{array}{l}\text { I I } \\
\text { Maximum } \\
\text { fibrinogen-related } \\
\text { antigen }\end{array}$} & 0.364 & NS & 0.339 & NS \\
\hline & & & & \\
\hline & 0.403 & $99 \%$ & 0.102 & NS \\
\hline
\end{tabular}


fibrinogen-related antigen values of $20 \mu \mathrm{g} / \mathrm{ml}$ or more and (b) those with values of $10 \mu \mathrm{g} / \mathrm{ml}$ or less. Means and standard deviations of the coronary prognostic index values of each group are given in Table 3 together with the value of ' $t$ '. Patients in category (a) had a mean coronary prognostic index value which was significantly greater than category (b).

Mean coronary prognostic values were calculated for patients with and without deep venous thrombosis. These are given in Table 4 .

\section{Discussion}

The fibrinogen-related antigen levels obtained in this study can be compared with the findings of previous studies: Baele et al. (1972) found raised serum values in 20 of 92 patients within 24 hours of admission after myocardial infarction. Almer et al., using a crude assay, demonstrated fibrinogenrelated antigen in the serum in only 6 of 92 patients whose blood was sampled within 48 hours. In our study 5 of 55 patients had raised values at 24 hours and only 7 were raised by 48 hours.

Almer et al. also found that approximately onethird of the patients had detectable fibrinogenrelated antigen at some time during their stay in hospital. This agrees with our findings in which 17 of the 55 patients had raised values during the period of study. All this evidence suggests that raised fibrinogen-related antigen values are not a standard finding after myocardial infarction and that the test is of little value in the diagnosis of myocardial infarction.

In the studies referred to above, the authors suggested that high fibrinogen-related antigen values are found in patients with serious infarcts and that a raised value obtained within 48 hours of infarction indicates a sinister prognosis. We are unable to confirm this proposal. We have assessed the severity and prognosis of myocardial infarction by calculating the coronary prognostic index (Norris et al., 1969). Our results indicate no correlation between coronary prognostic index, and fibrinogen-related antigen level during the first four days after admission. During this period patients with a high coronary prognostic index, and thus a poor prognosis, were just as likely to have high or low fibrinogen-related antigen values. The reverse was also true.

However, as indicated in Table 2, we have shown that prognostic information can be elicited from fibrinogen-related antigen levels obtained later in the period of study. We obtained a significant correlation between fibrinogen-related antigen level and coronary prognostic index from day 5 to day 8 whether all patients were considered or just those in whom deep venous thrombosis did not occur. The daily scatter of results was such that little prognostic weight can be attached to fibrinogen-related antigen values in individual patients. Certainly low fibrinogen-related antigen levels throughout do not necessarily indicate a good prognosis. When the maximum fibrinogen-related antigen level obtained is examined for its prognostic value, statistical analysis again shows that, whether all or only raised maxima are considered, higher levels are, overall, associated with poorer prognosis. We consider that there is no more prognostic value attached to the maximum fibrinogen-related antigen level than to any level obtained between day 5 and day 8 after myocardial infarction.

TABLE 3 Values of coronary prognostic index in patients with normal or raised fibrinogen-related antigen levels

\begin{tabular}{|c|c|c|c|c|c|c|}
\hline \multirow[b]{2}{*}{ Coronary prognostic index } & \multicolumn{2}{|c|}{$\begin{array}{l}\text { Fibrinogen-related } \\
\text { antigen } \\
\text { Maximum }>10 \mu \mathrm{g} / \mathrm{ml}\end{array}$} & \multicolumn{2}{|c|}{$\begin{array}{l}\text { Fibrinogen-related } \\
\text { antigen } \\
\text { Maximum } \leqslant 10 \mu \mathrm{g} / \mathrm{ml}\end{array}$} & \multirow{2}{*}{$\begin{array}{l}\text { ' } t \text { ' } \\
2.08\end{array}$} & \multirow{2}{*}{$\begin{array}{l}\text { Significance } \\
95 \%\end{array}$} \\
\hline & $\begin{array}{l}\text { Mean } \\
7 \cdot 36\end{array}$ & $\begin{array}{l}S D \\
3.05\end{array}$ & $\begin{array}{l}\text { Mean } \\
5.86\end{array}$ & $\begin{array}{l}S D \\
2 \cdot 08\end{array}$ & & \\
\hline
\end{tabular}

TABLE 4 Coronary prognostic index values for patients with and without deep venous thrombosis

\begin{tabular}{|c|c|c|c|c|c|}
\hline \multicolumn{4}{|c|}{ Coronary prognostic index } & \multirow[t]{3}{*}{ ' $t$ ' } & \multirow[t]{2}{*}{ Significance } \\
\hline \multicolumn{2}{|c|}{$\begin{array}{l}\text { Without deep venous } \\
\text { thrombosis }\end{array}$} & \multicolumn{2}{|c|}{$\begin{array}{l}\text { With deep venous } \\
\text { thrombosis }\end{array}$} & & \\
\hline $\begin{array}{l}\text { Mean } \\
6 \cdot 25\end{array}$ & $\begin{array}{l}S D \\
2 \cdot 64\end{array}$ & $\begin{array}{l}\text { Mean } \\
7 \cdot 20\end{array}$ & $\begin{array}{l}S D \\
2 \cdot 5\end{array}$ & & NS \\
\hline
\end{tabular}


Table 2 also indicates that there is an increased significance in the correlation coefficients when patients who develop deep venous thrombosis are included in the analysis, both when daily and maximum fibrinogen-related antigen levels are considered. However, these differences are small and we conclude that the presence or absence of deep venous thrombosis seems to have little influence on the prognostic value one can place on the fibrinogen-related antigen levels.

The results given in Table $I$ indicate that, on some days, fibrinogen-related antigen levels were significantly higher in patients with deep venous thrombosis. A 'paired t-test' indicated a significant overall rise. There are three possible explanations: a) fibrinolysis at the site of deep venous thrombosis may directly contribute to raised fibrinogen-related antigen levels; b) patients with large myocardial infarctions may have high fibrinogen-related antigen levels and may be more likely to develop deep venous thrombosis than patients with small infarctions; c) both these explanations may apply. We have evidence (Simmons, Sheppard, and Cox, 1973) that deep venous thrombosis is more likely to occur in those patients who develop dysrhythmias or heart failure, complications that occur more frequently in patients with large infarcts. However, Table 4 shows that, though the mean coronary prognostic index was higher in those patients who developed deep venous thrombosis, the difference was not significant. The contribution of the deep venous thrombosis itself to the fibrinogen-related antigen level found after myocardial infarction still awaits full resolution and is presently under study.

Three patients could be distinguished from the rest of the group on the basis of fibrinogen-related antigen values. Repeated high values, including levels of at least $80 \mu \mathrm{g} / \mathrm{ml}$, were obtained in these patients. Two of the three had very high coronary prognostic index values; all three developed severe heart failure. It seems possible that in some individual patients repeatedly high fibrinogen-related antigen levels may indicate severe myocardial infarction. The incidence of such patients is very low and the significance of these findings could only be ascertained statistically if data were available for a very large number of patients.
No patient developed major pulmonary embolism during the period of study. Minor pulmonary infarction was diagnosed in two patients. One had fibrinogen-related antigen levels raised to $20 \mu \mathrm{g} / \mathrm{ml}$ on the three days after diagnosis; normal values were found on each day in the other patient. However, this complication is difficult to diagnose and its true incidence in our study remains unknown. The effect of unrecognized pulmonary embolism on the fibrinogen-related antigen levels found in patients with myocardial infarction is not known and would be extremely difficult to assess.

We thank the consultant physicians at Bradford Royal Infirmary for permission to study patients under their care.

\section{References}

Almer, L. O., Hedner, U., and Nilsson, I. M. (1972). Serum fibrin/fibrinogen degradation products in acute myocardial infarction (letter). Lancet, $\mathbf{1}, 960$.

Baele, G., Mussche, M., and Vermeire, P. (1972). Serum fibrin/fibrinogen degradation products in acute myocardial infarction (letter). Lancet, I, 689.

Das, P. C., Allan, A. G. E., Woodfield, D. G., and Cash, J. D. (1967). Fibrin degradation products in sera of normal subjects. British Medical fournal, 4, 718 .

Merskey, C., and Johnson, A. J. (197I). The clinical significance of fibrinogen-fibrin-related antigen in serum. Scandinavian fournal of Haematology, Suppl. 13, p. 313.

Merskey, C., Kleiner, G. J., and Johnson, A. J. (I966). Quantitative estimation of split products of fibrinogen in human serum-relation to diagnosis and treatment. Blood, 28, 1 .

Norris, R. M., Brandt, P. W. T., Caughey, D. E., Lee, A. J., and Scott, P. J. (1969). A new coronary prognostic index. Lancet, $1,274$.

Simmons, A. V., Sheppard, M. A., and Cox, A. F. (1972). Plasma ${ }^{125}$ I-labelled fibrinogen clearance in diagnosis of deep venous thrombosis after myocardial infarction. British Heart fournal, 34, 7 I 1 .

Simmons, A. V., Sheppard, M. A., and Cox, A. F. (1973). Deep venous thrombosis after myocardial infarction. Predisposing factors. British Heart fournal, 35, 623.

Wood, E. H., Prentice, C. R. M., and McNicol, G. P. (1972). Association of fibrinogen-fibrin related antigen (F-R antigen) with post-operative deep-vein thrombosis and systemic complications. Lancet, I, 166.

Requests for reprints to Dr. A. V. Simmons, Chapel Allerton Hospital, Leeds 7. 